\title{
In vitro estimation of iron availability from a range of plant foods: influence of phytate, ascorbate and citrate
}

\author{
BY T. HAZELL AND I. T. JOHNSON \\ AFRC Institute of Food Research, Norwich Laboratory, Colney Lane, Norwich NR4 7UA
}

(Received 25 April 1986 - Accepted 20 October 1986)

\begin{abstract}
1. Plant foods were digested in vitro and the proportion of iron which diffused across a semi-permeable membrane was used as an index of Fe availability.

2. The mean (with SEM) Fe diffusibility from a group of eighteen cereals, legumes and nuts was very low, $2 \cdot 1$ $(0 \cdot 25) \%$, whereas from a group of sixteen fruits and vegetables it was high, $13 \cdot 7(1 \cdot 09) \%$. The difference between the two food groups was highly significant $(P<0.001)$.

3. The results for Fe diffusibility correlated well with literature values for the in vivo absorption of Fe from similar foods $(r 0.84, P<0 \cdot 01)$.

4. When phytate, citrate and ascorbate were added to selected foods in amounts corresponding to endogenous levels, only phytate and citrate gave the expected effects on Fe diffusibility. Ascorbate only enhanced $\mathrm{Fe}$ diffusibility to the expected extent when it was added in much larger amounts, not normally found in foods.

5. When added to cereal foods, orange juice was found to enhance greatly Fe diffusibility even when its content of ascorbate was completely destroyed by boiling followed by prolonged storage. When citrate and ascorbate were added to cereal foods in amounts equivalent to those found in fresh orange juice, both enhanced Fe diffusibility but citrate was far more effective.

6. It is concluded that phytate is a major inhibitor of Fe diffusibility in cereals, legumes and nuts. However, citrate rather than ascorbate would appear to be the major enhancer of Fe diffusibility from many fruits and vegetables.

7. The implications of the present results are discussed in relation to the relative influence of phytate, citrate and ascorbate on dietary $\mathrm{Fe}$ availability.
\end{abstract}

Low iron availability is considered to be one of the most significant factors in the aetiology of $\mathrm{Fe}$ deficiency. The absorption of non-haem-Fe in foods is influenced by a variety of inhibitors and enhancers of Fe absorption. For example, protein (Klavins et al. 1962; Abernathy et al. 1965), sugars (Pollack et al. 1964; Amine \& Hegsted, 1975), ascorbic acid (Hallberg, 1981) and citric acid (Christopher et al. 1974; Gillooly et al. 1983) have been shown to enhance $\mathrm{Fe}$ availability whereas phytic acid (Sharpe et al. 1950; Apte \& Venkatachalam, 1962), fibre (Reinhold et al. 1975; Fernadez \& Phillips, 1982) and tannins (Disler et al. 1975) tend to inhibit it.

Miller et al. (1981) have described an in vitro method that simulates human digestion and absorption of dietary Fe from complex meals. Both enhancing and inhibiting factors of $\mathrm{Fe}$ absorption have been shown to respond in vitro in the same way as they affect $\mathrm{Fe}$ absorption in vivo. A significant correlation was found between $\mathrm{Fe}$ absorption by humans in vivo and the in vitro method of Fe availability assessment (Schricker et al. 1981). Therefore this method allows a rapid and inexpensive estimation of the non-haem-Fe which is potentially available from foods and diets.

$\mathrm{Fe}$ availability is generally considered to be good from meat and fish but rather poor from plant foods (Layrisse \& Martinez-Torres, 1971). Unfortunately only cereals and legumes have been extensively studied. The present study was undertaken in order to estimate in vitro the relative availability of $\mathrm{Fe}$ from a wide range of plant foods, and to investigate the effects of components thought to influence Fe availability. 


\section{MATERIALS AND METHODS \\ Preparation of test foods}

A wide range of plant foods was purchased locally; they were fresh unless otherwise stated. The following foods were boiled for $15 \mathrm{~min}$ in distilled water before blending and digestion: oatmeal, wholemeal wheat flour, full-fat soya-bean flour, polished rice, white plain wheat flour, maize meal, broad beans (Vicia faba), lentils (Lens culinaris), parsnips (Pastinaca sativa), onions (Allium cepa), tapioca (Manihot utilissima), carrots (Daucus carota), cauliflower (Brassica oleracea var botrytis), potato (Solanum tuberosum) and swede (Brassica napus var napobrassica). The following foods were purchased as canned products and were tested without further heat treatment: peas (Pisum sativum), black beans (Phaseolus vulgaris), baked beans. All other foods were used raw. The weights of foods refer to the wet weights of the items as purchased.

The ascorbic acid in orange juice was partially destroyed by boiling for $45 \mathrm{~min}$ or completely destroyed (i.e. $<10 \mathrm{mg} / \mathrm{kg}$ ) by boiling for $3 \mathrm{~h}$ followed by storage in a half-full stoppered plastic bottle for 6 months at $1^{\circ}$. Such treatment did not substantially influence the level of citric acid in the orange juice. A $45 \mathrm{ml}$ portion of the orange juice was added to cooked wholemeal flour, cooked plain white flour, or to cooked oatmeal and the mixtures made up to $100 \mathrm{~g}$ with distilled water.

\section{Reagents}

Pepsin suspension. Pepsin powder (16 g; from porcine stomach mucosa; Sigma Chemical Co., Poole, Dorset) was suspended in $0.1 \mathrm{M}$-hydrochloric acid and brought to $100 \mathrm{ml}$ with $0 \cdot 1 \mathrm{M}-\mathrm{HCl}$.

Pancreatin-bile extract mixture. Pancreatin $(4 \mathrm{~g}$; from porcine pancreas; Sigma Chemical Co.) and bile extract ( $25 \mathrm{~g}$; porcine, Sigma Chemical Co.) were dispersed in $0.1 \mathrm{M}$-sodium bicarbonate and the mixture was brought to 1 litre with $0 \cdot 1 \mathrm{M}-\mathrm{NaHCO}_{3}$.

Dialysis tubing. Molecular weight cut-off of approximately 12000 (Medicell International L.td, London).

${ }^{59} \mathrm{Fe}$. Radioactive ${ }^{59} \mathrm{Fe}$ as ferric chloride in $0 \cdot 1 \mathrm{M}-\mathrm{HCl}$ was used $(7 \cdot 8 \mu \mathrm{g} \mathrm{Fe} / \mathrm{ml}$ and $100 \mu \mathrm{Ci} / \mathrm{ml}$, Amersham International plc, Amersham, Bucks).

\section{Analytical methods}

Digestion and dialysis. The release of diffusible $\mathrm{Fe}$ was determined according to the method of Miller et al. (1981). The foods were mixed with distilled water and homogenized in a blender to a creamy consistency, so as to give approximately $10 \mathrm{~g}$ dry matter $/ 100 \mathrm{~g}$ homogenate. After blending, the $\mathrm{pH}$ of the homogenates was adjusted to 2.0 with $6 \mathrm{M}-\mathrm{HCl}$. The homogenates were then spiked with ${ }^{59} \mathrm{Fe}$. Pepsin suspension $(3 \mathrm{ml})$ was added to each $100 \mathrm{~g}$ homogenized food sample which was then incubated in a shaking water-bath at $37^{\circ}$ for $2 \mathrm{~h}$. Duplicate $20 \mathrm{ml}$ samples of the pepsin digest were then transferred to $125 \mathrm{ml}$ plastic bottles. Segments of dialysis tubing containing $25 \mathrm{ml}$ distilled water and an amount of $\mathrm{NaHCO}_{3}$ equivalent to the titratable acidity measured previously (see p. 225) were placed in each bottle. The bottles were incubated in a shaking water-bath at $37^{\circ}$ for $30 \mathrm{~min}$. Pancreatin-bile-extract mixture $(5 \mathrm{ml})$ was added to each bottle and the incubation was continued for a further $2 \mathrm{~h}$. At the end of the incubation period the dialysis tubes were removed and the contents of each bottle (weight of retentate) and dialysis tube (volume of diffusate) were measured and analysed.

Measurement of diffusible ${ }^{59} \mathrm{Fe}$. Radioactivity in the diffusates and retentates was determined by counting 5-ml or 5-g samples in a Philips automatic gamma-counter. The percentage of diffusible (dialysable) ${ }^{59} \mathrm{Fe}$ was determined using the following equation: 


\author{
${ }^{59} \mathrm{Fe}$ (counts $/ \mathrm{min}(\mathrm{cpm}) / \mathrm{ml}$ diffusate) $\times$ diffusate $(\mathrm{ml}) \times 100 \%$ \\ $\overline{{ }^{59} \mathrm{Fe}(\mathrm{cpm} / \mathrm{ml} \text { diffusate }) \times \text { diffusate }(\mathrm{ml})+{ }^{59} \mathrm{Fe}(\mathrm{cpm} / \mathrm{g} \text { retentate }) \times \text { retentate }(\mathrm{g})}$.
}

In this equation, the volume of diffusate refers to the volume in the dialysis sac. Variations in the osmotic balance of the system did occasionally result in variations in the ratio of dialysate volume: total fluid volume. In fifty-four determinations involving twelve different foods the mean final volume in the dialysis sacs was 21.5 (SD 1.02) $\mathrm{ml}$. Such differences might conceivably affect the apparent diffusibility in a manner unrelated to any differences in availability of the Fe. However, no systematic effect of variation in volume on apparent diffusibility was observed.

The diffusates and retentates of ten food samples were also analysed for Fe by atomic absorption spectrophotometry and showed good agreement with results determined by measurement of ${ }^{59} \mathrm{Fe}$. Miller et al. (1981) also found good agreement between radioactive and chemical measurements of percentage diffusible Fe.

Titratable acidity. This was determined on 20-g samples of the pepsin digest to which $5 \mathrm{ml}$ of the pancreatin-bile-extract mixture had been added. Titratable acidity was defined as the number of equivalents of sodium hydroxide required to titrate the combined pepsin-digest-pancreatin-bile-extract mixture to $\mathrm{pH} 7 \cdot 0(0.5 \mathrm{M}-\mathrm{NaOH}$ was used in the titration).

Citrate and ascorbate. The citric acid content of certain foods and the ascorbic acid content of orange juice were determined using the respective food analysis kits (catalogue nos. 139076 and 409677, Boehringer Mannheim, Lewes, E. Sussex).

\title{
RESULTS
}

As can be seen from Table 1, the cereals, legumes and nuts all displayed Fe-diffusibility values below $6 \%$ (range $0.4-5.8 \%$ ) whereas the fruits and vegetables all displayed values above $5 \%$ (range $5 \cdot 1-28.5 \%$ ). Mean Fe diffusibility from eighteen different cereals, legumes and nuts was $2 \cdot 1$ (SEM 0.25$) \%$ whereas the value for sixteen different fruits and vegetables was 13.7 (SEM 1.09$) \%$. The difference between the two groups of foods was highly significant $(P<0.001)$.

In an attempt to account for this difference, a relation was sought between the results for diffusible $\mathrm{Fe}$ and the chemical composition of the foods. By reference to the literature (Hartmann \& Hillig, 1934; Watt \& Merrill, 1963; Diem \& Lentner, 1970; Oberleas, 1973; Wright \& Hughes, 1975; Paul \& Southgate, 1978), the correlation between Fe diffusibility and the levels of protein, sugar, fibre, phytate phosphorus, ascorbate and citrate was examined. None of the first three components showed any correlation with percentage diffusible $\mathrm{Fe}$ in either food group. Phytate-P was negatively correlated in the cerealslegumes-nuts group, but strong positive correlations between ascorbate and citrate levels and $\mathrm{Fe}$ diffusibility were found for fruits and vegetables.

This approach, although based on values drawn from many different sources, suggested a hypothesis which could be tested by adding citrate, ascorbate and phytate to selected foods in amounts corresponding to endogenous levels to see if they gave the expected response. Citrate and ascorbate were added to foods normally devoid of these components in a range of concentrations corresponding to those found in foods displaying high $\mathrm{Fe}$ diffusibility. Sodium phytate was added to three foods which normally contain low levels of this component, in a range of concentrations corresponding to those found in many of the foods displaying very low Fe diffusibility.

As can be seen from Fig. 1, the addition of phytate had a depressing effect on $\mathrm{Fe}$ diffusibility, whilst citrate had an enhancing effect on Fe diffusibility (Fig. 2). Both these 
Table 1. Iron diffusibility from a range of plant foods

(Mean values with their standard errors)

\begin{tabular}{|c|c|c|c|c|c|}
\hline \multirow[b]{2}{*}{ Cereals-legumes-nuts group } & \multicolumn{2}{|c|}{$\begin{array}{c}\text { Percentage } \\
\text { diffusible }{ }^{59} \mathrm{Fe}\end{array}$} & \multirow[b]{2}{*}{ Vegetables-fruits group } & \multicolumn{2}{|c|}{$\begin{array}{c}\text { Percentage } \\
\text { diffusible }{ }^{59} \mathrm{Fe}\end{array}$} \\
\hline & Mean & SEM & & Mean & SEM \\
\hline Brazil nuts & $0 \cdot 4$ & $0 \cdot 09$ & Parsnips (Pastinaca sativa) & $5 \cdot 1$ & 0.71 \\
\hline Walnuts & $0 \cdot 4$ & $0 \cdot 16$ & Cucumber (Cucumis sativa) & $5 \cdot 6$ & $0 \cdot 40$ \\
\hline Oatmeal & 0.5 & 0.06 & Onions (Allium cepa) & 6.0 & 0.47 \\
\hline Wholemeal bread & 0.7 & $0 \cdot 17$ & Celery (Apium graveolens) & $6 \cdot 7$ & 0.75 \\
\hline Wholemeal flour & $0 \cdot 9$ & $0 \cdot 11$ & Tapioca (Manihot utilissima) & $7 \cdot 1$ & 0.67 \\
\hline Almonds & $1 \cdot 0$ & 0.45 & Banana (Musa sp.) & $8 \cdot 2$ & $1 \cdot 17$ \\
\hline Broad beans (Vicia faba) & $1 \cdot 1$ & 0.09 & Carrots (Daucus carota) & $8 \cdot 7$ & 0.67 \\
\hline Wheat bran & $1 \cdot 2$ & $0 \cdot 15$ & Redcurrants (Ribes rubrum) & $11 \cdot 7$ & $1 \cdot 35$ \\
\hline Hazel nuts & 1.6 & $0 \cdot 10$ & Cauliflower (Brassica oleracea) & $12 \cdot 4$ & 0.45 \\
\hline Peas (Pisum sativum) & $1 \cdot 6$ & $0 \cdot 34$ & Paw paw (Carica papaya) & $13 \cdot 8$ & 0.82 \\
\hline Soya-bean flour & $2 \cdot 1$ & $0 \cdot 19$ & Potato (Solanum tuberosum) & $13 \cdot 9$ & $1 \cdot 03$ \\
\hline Lentils (Lens culinaris) & $2 \cdot 6$ & 0.44 & Swede (Brassica napus) & $19 \cdot 7$ & $1 \cdot 16$ \\
\hline Rice (Oryza sativa) & $2 \cdot 7$ & $0 \cdot 71$ & Tomato (Lycopersicon esculentum) & $20 \cdot 9$ & $1 \cdot 54$ \\
\hline White plain flour & $3 \cdot 4$ & 0.71 & Orange & $24 \cdot 2$ & $2 \cdot 57$ \\
\hline White bread & $3 \cdot 5$ & 0.65 & Lime & $25 \cdot 4$ & 1.23 \\
\hline Maize meal & $3 \cdot 8$ & 0.92 & Lemon & $28 \cdot 5$ & 2.06 \\
\hline $\begin{array}{l}\text { Black beans (Phaseolus } \\
\text { vulgaris) }\end{array}$ & 4.9 & 0.51 & & & \\
\hline Baked beans & $5 \cdot 8$ & $0 \cdot 83$ & & & \\
\hline Food group mean & $2 \cdot 1$ & $0 \cdot 25$ & Food group mean & $13 \cdot 7$ & 1.09 \\
\hline
\end{tabular}

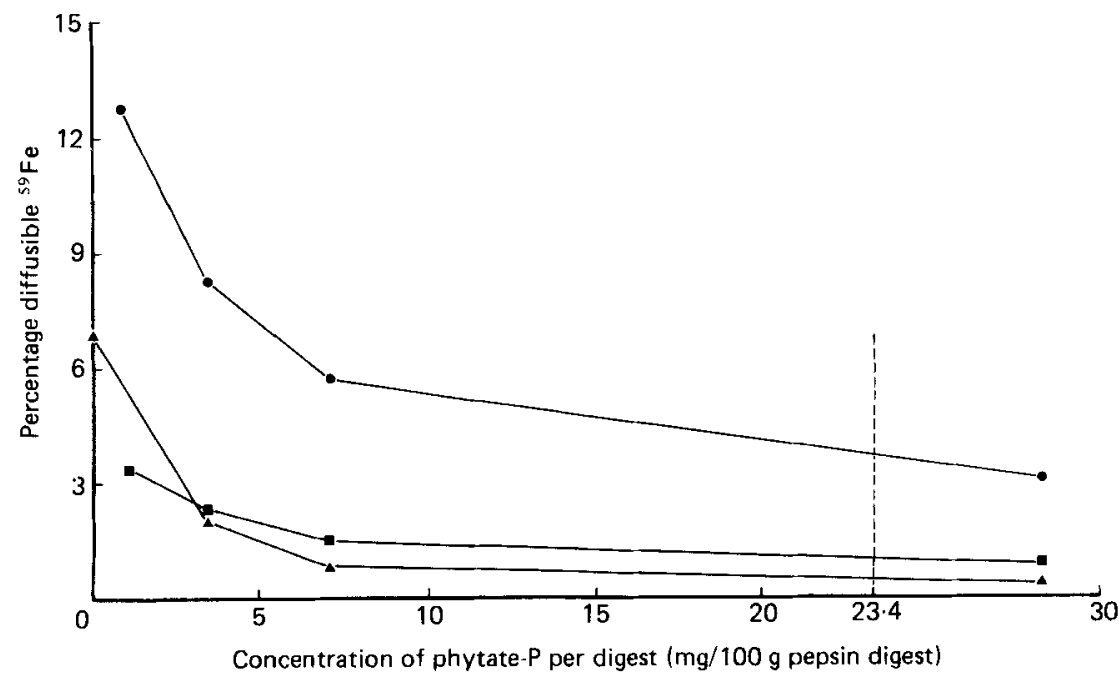

Fig. 1. The influence of exogenous phytic acid-phosphorus on iron diffusibility from certain plant foods. Potato (Solanum tuberosum) (-O); plain white wheat flour ( $-\mathbf{-}$ ); tapioca (Manihot utilissima) $(\boldsymbol{A}-\mathbf{A}) ;(--)$, a verage of literature values for each of the food items in the cereals-legumes-nuts group. 


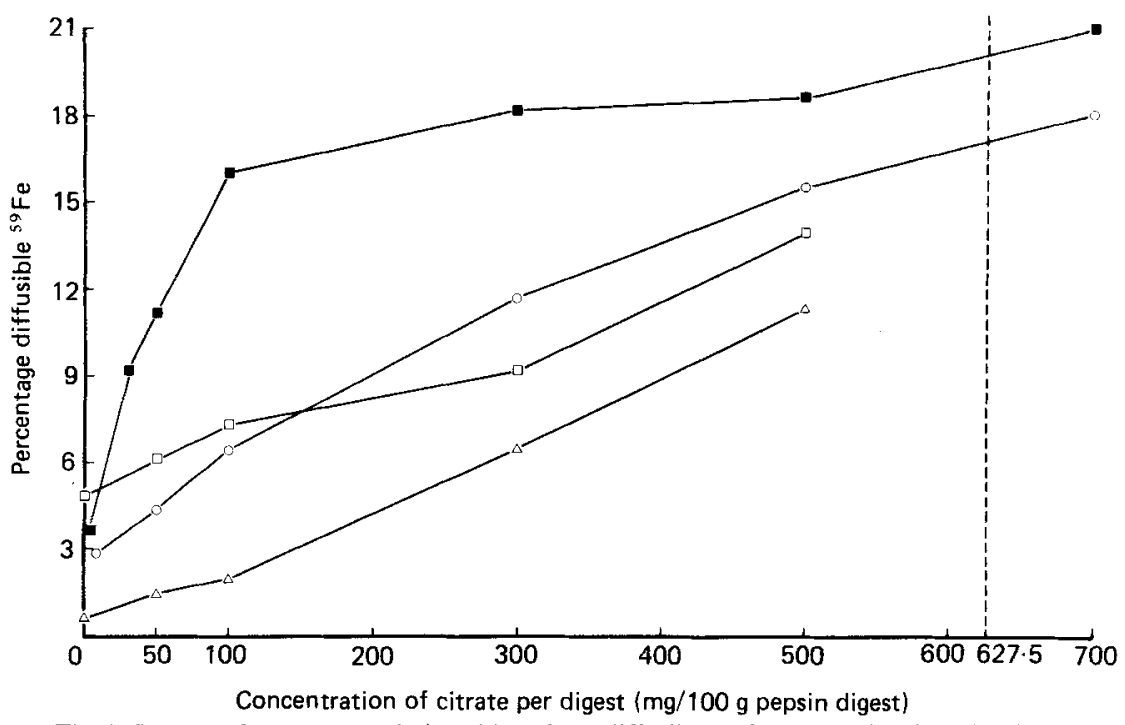

Fig. 2. The influence of exogenous citric acid on iron diffusibility from certain plant foods. Plain white wheat flour ( $\square-\square$ ); parsnip (Pastinaca sativa) $(\square-\square)$; full-fat soya-bean flour ( $\bigcirc-O)$; oatmeal $(\triangle-\triangle) ;(---)$, average of literature values for each of the food items in the vegetables-fruits group.

effects were consistent with what might be expected on the basis of the endogenous levels of these components. However, added ascorbate did not enhance Fe diffusibility to the extent that would be predicted from the levels of endogenous ascorbate (Fig. 3(a)). Only extremely high levels of ascorbic acid, which are not normally found in foods, were able to enhance Fe diffusibility (Fig. 3(b)).

The addition of $45 \mathrm{ml}$ fresh orange juice to various cereal foods greatly enhanced $\mathrm{Fe}$ diffusibility $(P<0.001$; Table 2$)$. Partial destruction of ascorbate by heat treatment appeared to have no detrimental effect on the ability of the orange juice to enhance $\mathrm{Fe}$ diffusibility, with enhancement still being highly significant $(P<0.001)$. Although total destruction of ascorbate (by heat treatment and prolonged storage) led to a reduction in diffusibility, enhancement was still highly significant compared with the control $(P<0.001)$. When citrate $(P<0.001)$ and ascorbate $(P<0.01)$ were added individually in amounts approximately corresponding to endogenous levels, both enhanced Fe diffusibility but citrate was far more effective. When both were added together the enhancement was equivalent to that observed with fresh orange juice $(P<0.001)$.

\section{DISCUSSION}

Early attempts to measure in vitro $\mathrm{Fe}$ availability by 'chemical' methods were not very successful because the results often did not reflect those obtained with human absorption studies (Shackleton \& McCance, 1936; McCance, 1939; Sanford, 1960). Recent attempts, where a 'physiological' approach has been used, have proved more successful (Narasinga Rao \& Prabhavathi, 1978; Lock \& Bender, 1980). The present method (Miller et al. 1981) differs from other simulated physiological methods in that the $\mathrm{pH}$ adjustment from gastric to intestinal levels is achieved gradually by the use of sodium bicarbonate inside dialysis tubing. This closely parallels the events occurring when food leaves the stomach and enters the duodenum. The use of diffusible-Fe measurements in the estimation of available $\mathrm{Fe}$ permits the discrimination between low- and high-molecular-weight soluble Fe compounds. 

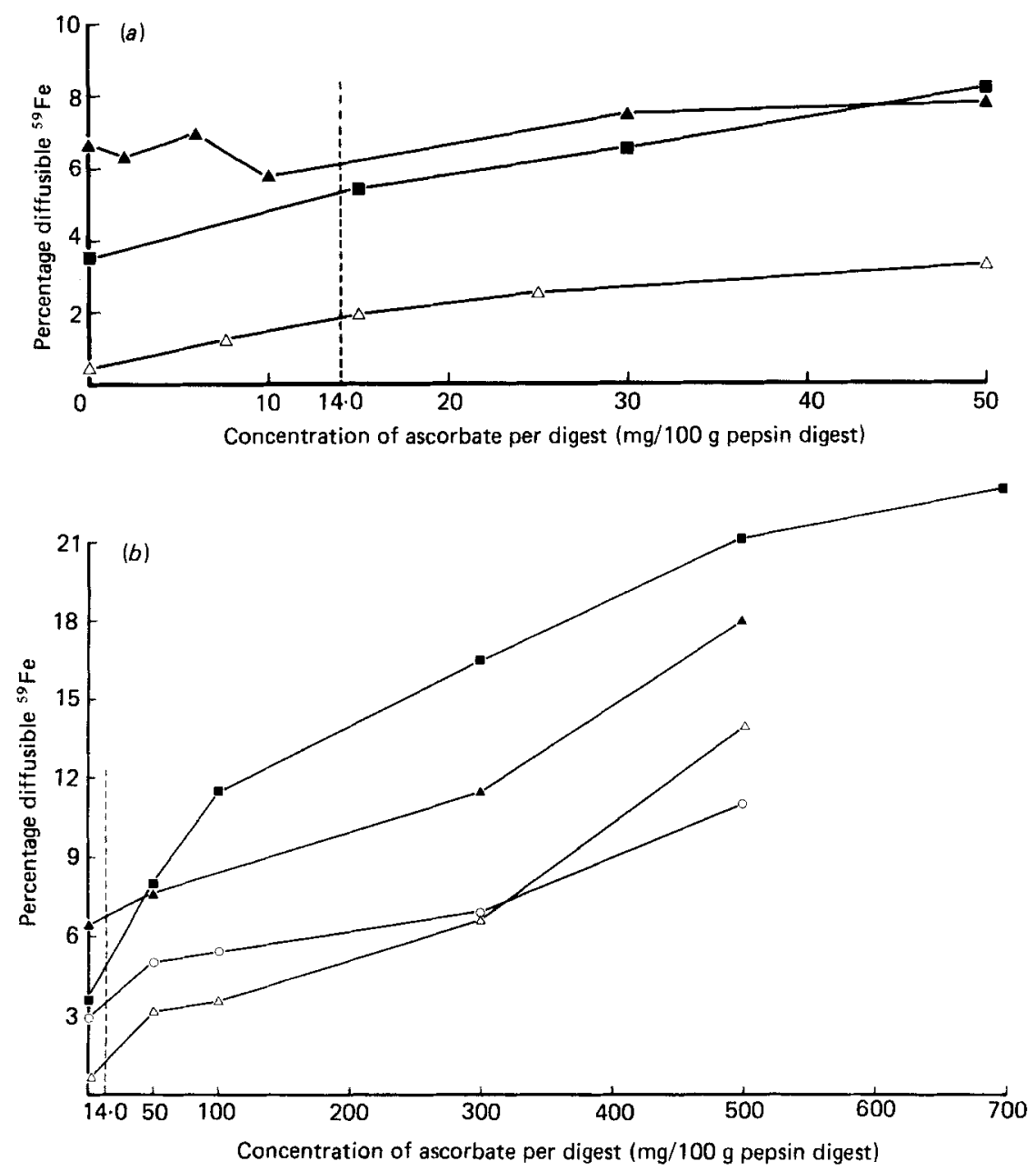

Fig. 3(a,b). The influence of exogenous ascorbic acid on iron diffusibility from certain plant foods. Tapioca (Manihot utilissima) $(\mathbf{\Delta}-\mathbf{\Delta})$; plain white wheat flour $(\boldsymbol{\square}-\mathbf{\square})$; oatmeal $(\triangle-\triangle)$; full fat soya-bean flour $(\mathrm{O}-\mathrm{O}) ;(--)$, average of literature values for each of the food items in the vegetables-fruits group.

This is not possible in methods using centrifugation to separate soluble from insoluble Fe. However, it is not possible to reproduce physiological conditions exactly, and physiological variables such as $\mathrm{Fe}$ status and transit times which would influence the digestion and absorption of Fe cannot be taken into account. Therefore the values for diffusible Fe must be viewed as relative rather than absolute indications of availability. Nevertheless, Schricker et al. (1981) found substantial agreement between diffusible $\mathrm{Fe}$ and $\mathrm{Fe}$ availability measured in vivo in human subjects. They found less agreement between human and rat measurements in vivo, and concluded that because of physiological differences the availability of food $\mathrm{Fe}$ to humans was more accurately estimated with in vitro measurements than with rat studies of the type used in their experiments.

The present in vitro results for Fe diffusibility show that the values for the foods studied fall into two groups (Table 1) and these groups correspond with those seen when availability is measured in vivo in man (Table 3). A significant correlation exists between differences in diffusible $\mathrm{Fe}$ observed in vitro and the response seen in human trials $(r 0.84, P<0.01)$. 


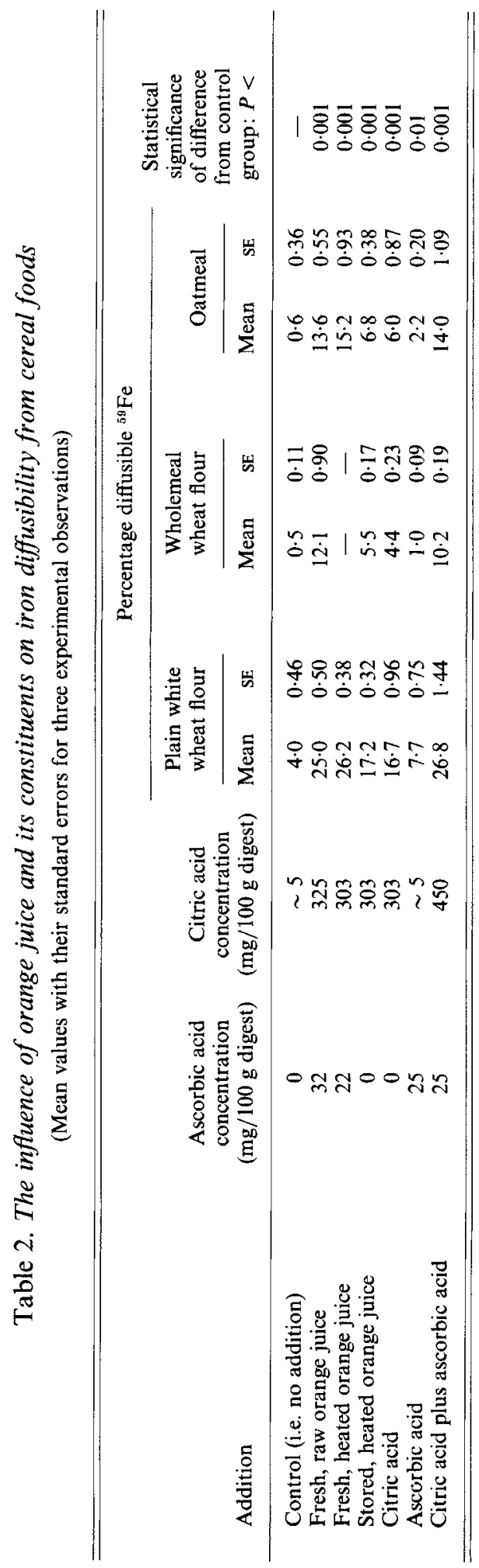


Table 3. Diffusible Fe estimated for plant foods by the present in vitro method compared with in vivo absorption studies using human subjects

\begin{tabular}{|c|c|c|}
\hline Food & In vitro $(\%)$ & In vivo $(\%)$ \\
\hline \multicolumn{3}{|l|}{ Cereals-legumes: } \\
\hline Wheat & 0.9 & $2 \cdot 7 * 5 \cdot 7 \dagger$ \\
\hline Broad beans (Vicia faba) & $1 \cdot 1$ & $5 \cdot 6 \pm$ \\
\hline Soya bean & $2 \cdot 1$ & $1.5^{*} 1 \cdot 7 \S 11 \cdot 0 \dagger$ \\
\hline Lentils (Lens culinaris) & $2 \cdot 6$ & $1 \cdot 2 \S 3 \cdot 2+$ \\
\hline Rice (Oryza sativa) & $2 \cdot 7$ & $1 \cdot 0+3 \cdot 8^{*}$ \\
\hline Maize & $3 \cdot 8$ & $3 \cdot 3 \| 4 \cdot 2 \dagger$ \\
\hline Black beans (Phaseolus vulgaris) & $4 \cdot 9$ & $0.8 \S 2.6 \dagger$ \\
\hline \multicolumn{3}{|l|}{ Vegetables: } \\
\hline Carrots (Daucus carota) & $8 \cdot 7$ & $9 \cdot 69$ \\
\hline Cauliflower (Brassica oleracea) & $12 \cdot 4$ & $26 \cdot 3 \cdot$ \\
\hline Potato (Solanum tuberosum) & $13 \cdot 9$ & $11 \cdot 59$ \\
\hline Tomato (Lycopersicon esculentum) & $20 \cdot 9$ & $22 \cdot 4 \uparrow$ \\
\hline
\end{tabular}

* Bjorn-Rasmussen et al. (1973). † Layrisse et al. (1969). † Mameesh et al. (1970). § Lynch et al. (1984). \| Cook et al. (1972). T Gillooly et al. (1983).

The marked difference between the vegetables, cereals and legumes is very clear in both sets of values (Table 3). High Fe-availability values have also been found in other human studies following consumption of vegetarian meals containing paw paw (Carica papaya) (Layrisse et al. 1974), cauliflower (Hallberg \& Rossander, 1982) or orange juice (Rossander et al. 1979). Low Fe-availability values have been reported in human subjects consuming meals predominantly consisting of cereals, legumes, or both (International Nutritional Anemia Consultative Group, 1982).

Reference to the literature and to our own analyses (T. Hazell and I. T. Johnson, unpublished results) suggests that cereals, legumes and nuts contain high levels of phytate but low levels of citrate and ascorbate whereas the reverse is true for vegetables and fruits. When these compounds were added to selected foods in amounts corresponding to endogenous levels, phytate produced the expected reduction in diffusible Fe (Fig. 1), citrate produced the expected enhancement of diffusible Fe (Fig. 2) but ascorbate did not (Fig. 3). This suggests that for many of the foods used in the present study, phytate and citrate may be the major determinants of Fe diffusibility, whilst ascorbate may be less important.

If it is assumed that endogenous phytate inhibits Fe diffusibility in the same way as added phytate, any food containing more than $10 \mathrm{mg}$ phytate-P/100 $\mathrm{g}$ digest would be expected to display low $\mathrm{Fe}$ diffusibility (Fig. 1). This corresponds to approximately $100 \mathrm{mg}$ endogenous phytate-P/100 $\mathrm{g}$ food and includes many of the cereals, legumes and nuts used in the present study but none of the vegetables or fruits. However, reference to the literature suggests that some of the legumes and cereal foods under study actually contain much lower concentrations of phytate-P. Such foods are common in the UK diet and hence total phytate-P intakes in the UK are not high, being in the region of $80 \mathrm{mg} /$ person per $\mathrm{d}$ (Hazell, 1985). Present results and other, in vivo studies (Hussain \& Patwardhan, 1959), would indicate that poor $\mathrm{Fe}$ availability would not be an inevitable consequence of this level of phytate-P consumption.

Assuming that endogenous citrate enhances Fe diffusibility in the same way as added citrate, any food containing more than $200 \mathrm{mg}$ endogenous citrate $/ 100 \mathrm{~g}$ digest would be expected to display relatively high $\mathrm{Fe}$ diffusibility (Fig. 2). This corresponds to approxi- 
mately $250 \mathrm{mg}$ endogenous citrate $/ 100 \mathrm{~g}$ food and would probably include many of the vegetables and fruits but none of the cereals, legumes or nuts used in the present study.

Fruits and vegetables consumed in the average UK diet contain approximately 22 and $8 \mathrm{mg}$ ascorbate $/ 100 \mathrm{~g}$ respectively. The results from Fig. 3(a) show that the previously stated levels of ascorbate would not be expected markedly to enhance Fe diffusibility nor to account for the high diffusibility displayed by many of these foods.

The influence of orange juice on the diffusibility of Fe from cereal foods was studied because orange juice contains large amounts of both ascorbate and citrate and because of its extensive use in studies of Fe availability (Moore \& Dubach, 1951; Callender et al. 1970; Rossander et al. 1979). The results shown in Table 2 reinforce the argument that it is the citrate content of certain foods which is responsible for their high Fe diffusibility rather than their ascorbate content. The results indicate that citrate is the component of orange juice mainly responsible for the enhancement of Fe diffusibility when this beverage is added to other foods (Table 2). Some enhancement is due to ascorbate but even when this component is completely destroyed orange juice is still able to enhance greatly $\mathrm{Fe}$ diffusibility (Table 2).

For white flour the effect of combined ascorbate and citrate was simply additive (Table 2). However, for wholemeal flour and oatmeal the effects of combined ascorbate and citrate were considerably greater than the sum of individual effects (Table 2), suggesting a possible synergistic mechanism. White flour is relatively free of phytate but wholemeal flour and oatmeal contain large amounts (Paul \& Southgate, 1978). It is perhaps possible that the ascorbate helps to maintain $\mathrm{Fe}$ in the ferrous form but $\mathrm{Fe}^{2+}$ is susceptible to precipitation as the mixed $\mathrm{Ca}$ phytate salt. Citrate may bind $\mathrm{Ca}$ and prevent this reaction, leaving the $\mathrm{Fe}$ predominantly in the ferric form. In contrast, if ascorbate is also present, the $\mathrm{Fe}^{2+}$ form may be generated, but not precipitated by phytate.

The level of citrate in the fresh orange juice used was approximately $700 \mathrm{mg} / 100 \mathrm{ml}$ (or $325 \mathrm{mg} / 100 \mathrm{~g}$ digest) whereas the level of ascorbate was approximately $70 \mathrm{mg} / 100 \mathrm{ml}$ (or $32 \mathrm{mg} / 100 \mathrm{~g}$ digest). The results in Table 2 indicate that at these approximate concentrations citrate greatly enhances Fe diffusibility but that enhancement due to ascorbate is much lower.

If ascorbic acid is not the most important determinant of Fe diffusibility in the foods used in the present study, what is its importance with respect to Fe absorption from such foods or from diets containing these foods? Ascorbic acid has been mentioned as a possible panacea for Fe deficiency (Monsen, 1982) and it is frequently described as the major dietary determinant of Fe availability (Hallberg, 1981; Monsen, 1982). Indeed, predictive estimations of dietary $\mathrm{Fe}$ availability have been developed which are based on dietary ascorbic acid levels (Monsen et al. 1978). However, close inspection of studies involving the use of ascorbate to enhance Fe absorption in vivo show that ascorbate levels normally encountered in unsupplemented diets would only be expected to improve $\mathrm{Fe}$ absorption to a small extent. Numerous human studies have shown that large increases in Fe absorption only occur when at least $50 \mathrm{mg}$ ascorbate are present per meal (Lee et al. 1967; Sayers et al. 1974; Cook \& Monsen, 1977; Morck et al. 1981; Solomons \& Viteri, 1982; Gillooly et al. 1984).

Likewise, the present in vitro study shows that at least $50 \mathrm{mg}$ ascorbate are required per digest for a marked enhancement of Fe diffusibility (Fig. 3(a,b)). The total daily intake of ascorbate from the average UK diet is only $57 \mathrm{mg}$ (Ministry of Agriculture, Fisheries and Food, 1985). Therefore the average ascorbate content of any one meal would be unlikely to have a large influence on Fe availability.

On the other hand, dietary intakes of citrate have been estimated at $2 \mathrm{~g} / \mathrm{d}$ (Wright \& 
Hughes, 1975). Intakes from the average UK diet are probably similar, with the average concentration in fruits and vegetables being respectively approximately $400 \mathrm{mg}$ and $300 \mathrm{mg}$ citrate $/ 100 \mathrm{~g}$ food. The present study implies that approximately $250 \mathrm{mg}$ citrate $/ 100 \mathrm{~g}$ food is enough to enhance greatly Fe diffusibility. Therefore the citrate concentration in many foods eaten in the UK would be enough to have a very large influence on Fe diffusibility from those foods, or from meals containing those foods.

In conclusion, the present results show that both citrate and ascorbate have the potential to enhance greatly Fe diffusibility from various foods (see Figs 2 and $3(b)$ ). However, only citrate is naturally present at levels where enhancement would be expected to occur. If it is accepted that the present in vitro technique provides a good indication of Fe absorption (Table 3) then the present results imply that in the average UK diet, citrate is a more important determinant of Fe availability than ascorbate. The present results, and results in vivo (Layrisse et al. 1974; Hallberg \& Rossander, 1982; Gillooly et al. 1983), also imply that plant foods which contain high levels of citrate but low levels of inhibitors will contain highly available Fe.

The authors would like to thank Dr D. A. T. Southgate for helpful discussions during this study and J. G. Franklin for help and advice regarding the statistics. This work was funded by the Ministry of Agriculture, Fisheries and Food.

\section{REFEREN CES}

Abernathy, R. P., Miller, J., Wentworth, J. \& Speirs, M. (1965). Journal of Nutrition 85, 265-270.

Amine, E. K. \& Hegsted, D. M. (1975). Journal of Agricultural and Food Chemistry 23, 204-206.

Apte, S. V. \& Venkatachalam, P. S. (1962). Indian Journal of Medical Research 50, 516-520.

Bjorn-Rasmussen, E., Hallberg, L. \& Walker, R. (1973). American Journal of Clinical Nutrition 26, 1311-1319.

Callender, S. T., Marney, S. R. \& Warner, G. R. (1970). British Journal of Haematology 19, 657-665.

Christopher, J. P., Hegenauer, J. C. \& Saltman, P. D. (1974). In Trace Element Metabolism in Animals, vol. 2, pp. 133-145 [W. G. Hoekstra, J. W. Suttie, H. E. Ganther and W. Mertz, editors]. London: Butterworths.

Cook, J. D., Layrisse, M., Martinez-Torres, C., Walker, R., Monsen, E. \& Finch, C. A. (1972). Journal of Clinical Investigation 51, 805-815.

Cook, J. D. \& Monsen, E. R. (1977). American Journal of Clinical Nutrition 30, 235-241.

Diem, K. \& Lentner, C. (1970). Documenta Geigy Scientific Tables, 7th ed. Basle: J. R. Geigy SA.

Disler, P. B., Lynch, S. R., Charlton, R. W., Torrance, J. D., Bothwell, T. H., Walker, R. B. \& Mayet, F. (1975). Gut 16, 193-260.

Fernandez, R. \& Phillips, S. F. (1982). American Journal of Clinical Nutrition 35, 107-112.

Gillooly, M., Bothwell, T. H., Torrance, J. D., MacPhail, A. P., Derman, D. P., Bezwoda, W. R., Mills, W., Charlton, R. W. \& Mayet, F. (1983). British Journal of Nutrition 49, 331-342.

Gillooly, M., Torrance, J. D., Bothwell,T. H., MacPhail, A. P., Derman, D., Mills W. \& Mayet, F. (1984). American Journal of Clinical Nutrition 40, 522-527.

Hallberg, L. (1981). In Vitamin C (Ascorbic Acid), pp. 49-61 [J. M. Counsell and D. H. Hornig, editors]. London: Applied Science Publishers.

Hallberg, L. \& Rossander, L. (1982). American Journal of Clinical Nutrition 35, 502-509.

Hartmann, B. G. \& Hillig, F. (1934). Journal of the Association of Official Agricultural Chemists 27, 522-531.

Hazell, T. (1985). World Review of Nutrition and Dietetics 46, 1-123.

Hussain, R. \& Patwardhan, V. N. (1959). Indian Journal of Medical Research 47, 676-682.

International Nutritional Anemia Consultative Group (1982). Iron Absorption from Cereals and Legumes. New York: The Nutrition Foundation.

Klavins, J. V., Kinney, T. D. \& Kaufman, N. (1962). British Journal of Experimental Pathology 43, $172-180$.

Layrisse, M., Cook, J. D., Martinez-Torres, C., Roche, M., Kuhn, I. N., Walker, R. B. \& Finch, C. A. (1969). Blood 33, 430-443.

Layrisse, M. \& Martinez-Torres, C. (1971). In Progress in Haematology, vol. 7, pp. 137-160 [E. B. Brown and C. V. Moore, editors]. New York: Grune and Stratton.

Layrisse, M., Martinez-Torres, C. \& Gonzalez, M. (1974). American Journal of Clinical Nutrition 27, $152-162$.

Lee, P. C., Ledwich, J. R. \& Smith, D. C. (1967). Canadian Medical Association Journal 97, 181-184.

Lock, S. \& Bender, A. E. (1980). British Journal of Nutrition 43, 413-420.

Lynch, S. R., Beard, J. L., Dassenko, S. A. \& Cook, J. D. (1984). American Journal of Clinical Nutrition 40, $42-47$.

McCance, R. A. (1939). Chemistry and Industry 11, 528- 530. 
Mameesh, M. S., Aprahamian, S., Salji, J. P. \& Cowan, J. W. (1970). American Journal of Clinical Nutrition 23, 1027-1032.

Miller, D. D., Schricker, B. R., Rasmussen, R. R. \& Van Campen, D. (1981). American Journal of Clinical Nutrition 34, 2248-2256.

Ministry of Agriculture, Fisheries and Food (1985). Household Food Consumption and Expenditure, 1983. London: H.M. Stationery Office.

Monsen, E. R. (1982). In Nutritional Bioavailability of Iron, pp. 85-95 [C. Kies, editor]. Washington, DC: American Chemical Society.

Monsen, E. R., Hallberg, L., Layrisse, M., Hegsted, D. M., Cook, J. D. Mertz, W. \& Finch, C. A. (1978). American Journal of Clinical Nutrition 31, 134-141.

Moore, C. V. \& Dubach, R. (1951). Transactions of the Association of American Physicians 64, 245-256.

Morck, T. A., Lynch, S. R., Skikne, B. S. \& Cook, J. D. (1981). American Journal of Clinical Nutrition 34, 2630-2634.

Narasinga Rao, B. S. \& Prabhavathi, T. (1978). American Journal of Clinical Nutrition 31, 169-175.

Oberleas, D. (1973). Toxicants Occurring Naturally in Foods, 2nd ed. Washington, DC: National Academy of Sciences.

Paul, A. A. \& Southgate, D. A. T. (1978). McCance and Widdowson's The Composition of Foods, 4th ed. London: H.M. Stationery Office.

Pollack, S., Kaufman, R. M. \& Crosby, W. H. (1964). Blood 24, 577-581.

Reinhold, J. G., Ismail-Beigi, F. \& Faradji, B. (1975). Nutrition Reports International 12, $75-85$.

Rossander, L. L., Hallberg, L. \& Bjorn-Rasmussen, E. (1979). American Journal of Clinical Nutrition 32. $2484-2489$.

Sanford, R. (1960). Nature 185, 533-534.

Sayers, M. H., Lynch, S. R., Charlton, R. W., Bothwell, T. H., Walker, R. B. \& Mayet, F. (1974). British Journal of Nutrition 31, 367-375.

Schricker, B. R., Miller, D. D., Rasmussen, R. R. \& Van Campen, D. (1981). American Journal of Clinical Nutrition 34, 2257-2263.

Shackleton, L. \& McCance, R. A. (1936). Biochemical Journal 30, 582-591.

Sharpe, L. M., Peacock, W. C., Cooke, R. \& Harris, R. S. (1950). Journal of Nutrition 41, 433-446.

Solomons, N. W. \& Viteri, F. E. (1982). In Ascorbic Acid: Chemistry, Metabolism, and Uses, pp. 551-569 [P. A. Sieb and B. M. Tolbert, editors]. Washington DC: American Chemical Society.

Watt, B. K. \& Merrill, A. L. (1963). Composition of Foods, Agriculture Handbook no. 8. Washington, DC: United States Department of Agriculture.

Wright, E. \& Hughes, R. E. (1975). Nutrition (London) 29, 367-372. 